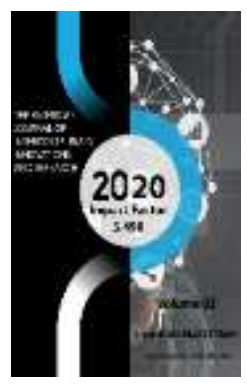

\title{
The Role Of Baihua In Chinese Linguistics
}

\author{
Feruza Khasanova
}

Senior Teacher, Tashkent State University Of Oriental Studies, Tashkent, Uzbekistan

Journal Website: http://usajournalshub.c om/index,php/tajiir

Copyright: Original content from this work may be used under the terms of the creative commons attributes 4.0 licence.

\section{ABSTRACT}

This article discusses the situation in Chinese linguistics before the founding of the Republic of China, the status of the Baihua language, the "may 4 movement" for the Baihua language and its consequences. As a result of the widespread introduction of the Baihua language, which served as an important factor in the formation of the modern Chinese language, a number of reforms were carried out in Chinese linguistics. The relevance of each reform gained practical significance.

\section{KEYWORDS}

Baihua, "may 4 movement", writing reform, Chinese alphabets, puntunghua.

\section{INTRODUCTION}

The relationship between Venyan and Baihua has a very long history. Already in the middle ages, elements of a written literary language based on oral speech, later called baihua, gradually won a place in society. The Qinghai Revolution of 1911 and the "may 4 movement" of 1919 called for the abandonment of Venyan and the transition to Baihua and the use of Baihua in all spheres of public life. “may 4 movement” “五四白话文运动Wǔsì báihuàwén yùndòng The "may 4 Baihua movement" is a movement calls for the introduction of the Baihua language [1].

After the Qinghai Revolution and the "may 4 movement", in a period of political struggle and chaos, a stratum of revolutionary intellectuals opposed traditional Chinese 
culture and Confucian teachings. A.A. Torchinov noted that nihilism (Nihilism (Latin nigil - nothing) - the denial of existing social life forms and moral norms, cultural heritage and ideals) arose during this period, and along with philosophical and ideological tendencies, protests arose against the Venyans, who were part of the "feudal" heritage [2].

During the "may 4 movement", several literary societies emerged in different directions. The translation work of writers acquired great importance, and classical works began to be translated into baihua. Lu Xin supported this process and welcomed the initiative to transform Venyan's classics into baihua. It should be noted that Baihua began to master the classical Chinese works of Venyang and the masterpieces of European languages, as well as grammatical and syntactic models of European languages. However, Venyanisms were also present in these translated works. A.M. Kotov noted that "no matter how casually they looked at Venyan, they could not have made a perfect translation without Venyan's attractive language “[3]. Since 1918 “新青年Xīn qingnián New youth" the newspaper began to be published in Baihua using new punctuation. It should be noted that the issue of punctuation in texts in classical literary monuments requires special attention. Although there were no punctuation marks, some hieroglyphs performed the functions of these punctuation marks. For example, interrogation in Vienna 乎 and 舆represented by placing the hieroglyph at the end of the sentence[4].

In China, the "may 4 movement" was the culmination of the educational movement[5]. Like the education movement in the West, the renewal of language and writing in China's education system has become a pressing issue. In the West, Latin was replaced by modern Western languages and in China, Venyan was replaced by Baihua.
Language and writing issues in China are more complex than in the West. In addition to combining traditional written methods with oral speech, issues of shaping the normative pronunciation of the vernacular, the complexity of hieroglyphic writing, and the large number of hieroglyphs also played an important role. Consequently, in China, along with language reform, writing reform also required that it be carried out harmoniously[6].

周有光Zhou Yu Guang stresses that after the language reform, the issue of writing should also be taken into account. Because he wrote that a national literary language will be practically ideal only if it includes phonetic, grammatical and written features based on a single norm. The writing reform naturally demanded a serious consideration of the questions of the Chinese hieroglyphic writing. 周有光Zhou $\mathrm{Yu}$ Guang made a number of recommendations and suggestions for this initiative. "Writing reform" or "Chinese character reform" covers almost two aspects: "Writing" - simplification of hieroglyphs and the introduction of the alphabet, as well as 普 通话Pǔtōnghuà - popularization of the national literary language. In addition to the three main tasks listed, there are a number of important tasks to create a simplified and unique language that defines the following tasks:

- Sorting hieroglyphs (by determining the number of hieroglyphs);

- Simplification of their writing; modeling of reading hieroglyphs;

- Unification of the hieroglyphic dictionary system;

- Reduction of different readings of hieroglyphs;

- Normalization of phonetic assimilation;

- To promote the idea of a unified translation of assimilations, i.e. reduce the difference in translations; 
- A unification of terms entering the scientific, technical and social fields (For example, the term "laser" was first translated by the method of phonetic assimilation and “来赛laisai" and later began to be translated “激光jiguang” was translated differently outside of continental China “镭射lieshe ");

- Reduction of the number of homonyms;

- Publication of various terminological dictionaries;

- Teacher training for popularization of the national language[7].

Thus, Baihua not only developed as a literary language, but also demanded a reform of the Chinese writing system. There were a number of reasons for this, one of which was that the large number of characters pronounced uniformly in Chinese was determined by the difficulty of writing characters. 周有光One of the challenges that Zhou Yu Guang pointed out was the transition to alphabetic writing. A lot of work has been done in China to solve this problem. First, the first alphabet in 1913 注音字 母 was created, and in 1919 put into circulation as an auxiliary record. In 1920 罗马字母the Latin alphabet was created and officially introduced in 1930 as the second form of the national alphabet. Attempts to convert hieroglyphic writing to alphabetic during the reform of writing were unsuccessful. The main reason for this was based on the presence of other nations and dialects in China besides the Khan nation. On February 3, 1957, at the session of the National People's Congress 拼音字母the alphabet was adopted as an auxiliary tool to facilitate the reading of hieroglyphs. 拼音字母 The main function of the alphabet was to decipher the hieroglyphs of the baihua text. However, none of the alphabets could serve as an autonomous means of writing in Chinese.

In the next step, efforts were made to simplify the hieroglyphs. Traditional hieroglyphs from 1956-1958 (繁体字) to a simplified form of writing (简体字) changed. A total of 502 hieroglyphs were written in笔画, that is, the lines and keys of the hieroglyphs, the side segments were abbreviated[8].

The peculiarity of the early Chinese alphabets was that they were not intended to be used in place of the Chinese characters. The authors who designed each alphabet first set themselves the goal of eradicating illiteracy in China at that time. We all know that during the time of the Qing dynasty in crisis, illiteracy was growing in China. Under such conditions, all efforts were made to educate the common people.

At the end of the first decade of the XX century, the leading figures of Chinese education were well aware that the most important factor in eradicating illiteracy is the reform of writing, improving the culture and education of the people. They were also well aware that in order to organize national unity, a single spoken language was needed in China. Written reforms and nationwide language problems intersected at one point. The only point was the alphabetical writing. Whatever the subsequent development of hieroglyphic writing, the alphabet was an important means of writing, and it was necessary to use the alphabet as an adjunct to hieroglyphic writing.

The common Chinese language was originally called官话Guānhuà, then the term国语Guóyŭ was used. In 1955, it was officially called 普通话 Pǔtōnghuà. 周有光 Zhou Yu Guang states in his article that the term “普通话Pǔtōnghuà" existed as early as the end of the Qing Dynasty, meaning "a common language understood by all”. Officially adopted in 1955, 普通话 said to Pǔtōnghuà: "The common language of the Chinese nation based on Northern dialects, The pronunciation standard is Peking, and the grammatical one is called "Baihua's work samples[9]. 
The period from the "may 4 movement" to the official announcement of 普通话Pǔtōnghuà the national literary language in 1955 is, according to the Uzbek Chinese scientist A.A. Karimov, a "buffer zone". The "buffer zone" of this period was occupied by the Baihua language, which not only removed Venyan from literature, linguistics and all other social spheres, but also laid the foundation for a popular common literary language -普通话 Pǔtōnghuà, understandable for many nationalities living in China.

During Baihua's tenure as a "buffer zone", the Chinese language underwent significant changes. From May 4, 1919, until普通话 Pǔtōnghuà was officially declared a state language, there were revolutionary changes in terms of linguistics, such as the elimination of illiteracy, the reform of hieroglyphic writing, and attempts to switch to alphabetic writing. In addition to the listed activities, the "may 4 movement" also laid the foundation for the study of Chinese dialects. Modern Chinese dialectology begins with the "may 4 movement" in 1919. Expeditionary research dialects was founded by researchers of people songs and folklore. "Song is a dialect," said Shen Jianshi - The lyrics of the song give more or less information about where the songs were sung. If the study of songs is connected with the study of their content, psyche and melody, we will miss the dialect. Therefore, the study of folklore is the most necessary condition in the study of dialects "[10].

The formation of the grammar of the national language required the creation of its normative pronunciation, normative grammar and normative vocabulary. To satisfy this demand, Chinese linguistics could only do this by using its scientific potential. Traditional Chinese linguistics first studied pronunciation, text analysis, and lexicography of the ancient Chinese. The acceptance of the concept of grammar as a system of language was learned by rote in the concept of traditional Chinese linguistics. Linguists were well aware of the difference between independent and auxiliary word groups in Chinese. Accordingly, dictionaries and text annotations used to comment on which word group the word belonged to. However, independent and auxiliary word groups were interpreted in the same traditional lexicographic form. In the XVIII-XIX centuries, Chinese linguists created collections of word interpretations by interpreting their belonging to the word family.

The "may 4th movement" led to the creation of dozens of works on Chinese grammar. Although some of them devoted themselves to studying the ancient Chinese, in most cases they were commentaries on国语. Such textbooks of grammar include "The Use of Auxiliary Words in the National Language" by Dei Weichin, "Baihua Grammar" by Zhang Tinghua, Examples include Xu Dishan's "Grammar of Oral Communication Method" and L. Jin's "National Grammar of the National Language". While Xu Dishan and Zhang Tinghua were the source of oral communication at the time, Dei Weiqin and $\mathrm{Li}$ Jingxi used the Baihua novels as a source of grammar.

Thus, we can conclude from the above considerations that by the time of the Min and Qing dynasties, baihua had taken its place in public life. Now not only natural works, samples of folklore, but also press releases are published in the baihua.

From the "may 4 movement", 1919, to the transition to Putonghua in 1955, a "buffer zone" arose in Chinese linguistics. It was during this period that revolutionary changes and reforms were made in the Chinese language, in which the direct influence of the baihua was great.

Periodicals first publish journalistic articles written in small columns on baihua, and then 
the entire volume of newspapers began to move to baihua. One by one, the number of newspapers in Baihua increased. The main purpose of the transition to Baihua was to eradicate illiteracy at the end of the Qing dynasty. Many language reforms have been implemented to achieve this goal. First, the issue of simplifying hieroglyphic writing shifted from traditional hieroglyphic writing to simplified writing. The sides and keys of the 502 characters have been simplified. Baihua's (spelling strings) have been shortened.

After the transition to Baihua, the question arose about the alphabetic character of the Chinese language. Special linguistic groups worked to develop an alphabet that was appropriate and specific to the Chinese language. Initially, 注音字母, and later拼音字 母, the Latin-based alphabet was introduced. However, alphabets that did not reflect the polyphonic features of the Chinese language did not give the expected result. Only hieroglyphs began to be used to facilitate reading.

In addition, books on modern Chinese grammar were written on the basis of the works of Baihua and received worldwide recognition in linguistics. Linguists such as Wang Li, Gao Mingkai, Liu Shuxiang, who were well versed in the science of Western linguistics, approached the Chinese language from the point of view and presented a Chinese grammar based on the characteristics of the Chinese language. In addition to works devoted to the study of Chinese grammar, projects on the study of dialects based on baihua were also launched, which became the basis for the formation of Chinese dialects as a science from a scientific point of view.

At the end of the Qing Dynasty, Baihua replaced Venyan and established himself not only in fiction and journalism, but also in science and management. According to Baihua, the "may 4 Movement" was primarily aimed at eradicating illiteracy in the country.
After the official recognition of the Baihua language, we recognize that in the short period from 1919 to 1955, the "buffer zone" - a period of great reforms in Chinese linguistics - was a turning point at every level of the language.

\section{REFERENCES}

1. Kondratyeva $\mathrm{E}$. The fate of the venyan after the Xinhai revolution. // Problems of the Far East №2, 2012 ,P. 176.

2. Torchinov E.A. Heidegger and Traditionalist Thought in 2oth Century China.

http://anthropology.ru/ru/texts/torchin/hei deast_o7html (date of the application 12.11.11)

3. Kotov A.M. The stylistic status of Venyanisms in the modern Chinese literary language // Answ. linguistics.1987. № 5.

4. Shichko V.F., Radus L.A., Abdurakhimov L.G. A course of lectures on the history of the Chinese language. Moscow:, 2015, P.110.

5. 周有光。中国语文的现代化。//教育研究, 1984 年, 1号, 33-40 页。Zhōu Yuguāng. Zhōngguó yǔwén de xiàndàihuà.//Jiàoyù yánjiū, 1984 nián,1 hào,33-40 yè. Zhou Yu Guang. Modernization of the Chinese language and literature. Educational research. 1984, №1, P.P.33-40.

6. 周有光。中国语文的现代化。//教育研究, 1984 年, 1号, 33-40 页。Zhōu Yuguāng. Zhōngguó yǔwén de xiàndàihuà.//Jiàoyù yánjiū, 1984 nián,1 hào,33-40 yè. Zhou Yu Guang. Modernization of the Chinese language and literature. Educational research. 1984, №1, P. 37.

7. 周有光。中国语文的现代化。//教育研究, 1984 年, 1号, 33-40 页。Zhōu Yuguāng. Zhōngguó yǔwén de xiàndàihuà.//Jiàoyù yánjiū, 1984 nián,1 hào,33-40 yè. Zhou Yu 
Guang. Modernization of the Chinese language and literature. Educational research. 1984, №1, P. 36.

8. V.F.Shchichko, L.A. Radus, L.G.

Abdurakhimov. A course of lectures on the history of the Chinese language. Moscow:, 2015, P.108.

9. 周有光。中国语文的现代化。//教育研究, 1984 年, 1号, 33-40 页。Zhōu Yuguāng. Zhōngguó yǔwén de xiàndàihuà.//Jiàoyù yánjiū, 1984 nián,1 hào,33-40 yè. Zhou Yu guang. Modernization of the Chinese language and literature. Educational research. 1984 , №1, P. 38.

10. Sofronov M.V. Introduction to Chinese. Moscow:, Publishing house Muravei, 1996. P. 172 . 